\title{
KEBERSIHAN DAN KESEHATAN PADA KEPADATAN TINGGI
}

\author{
Glenda Wongso ${ }^{1)}$, J.M. Joko Priyono ${ }^{21}$ \\ 1)Program Studi S1 Arsitektur, Fakultas Teknik, Universitas Tarumanagara, Glendawgs@gmail.com \\ ${ }^{2)}$ Program Studi S1 Arsitektur, Fakultas Teknik, Universitas Tarumanagara, jokop@ft.untar.ac.id
}

\begin{abstract}
Abstrak
Dunia diguncang pada awal tahun 2020 dengan berita Virus Covid-19. Indonesia menjadi salah satunya negara yang terkena dampaknya, terutama di Jakarta yang sampai saat ini masih menjadi kawasan zona merah, dimana salah satunya adalah kawasan Pademangan Barat di Jakarta Utara yang merupakan salah satu kawasan dengan kasus Covid-19 tertinggi di Jakarta. Pademangan Barat merupakan kawasan permukiman dengan kepadatan penduduk yang tinggi, kumuh dan fasilitas umum yang terbatas untuk menunjang kawasan tersebut. Rancangan ini bertujuan untuk mengurangi kepadatan bangunan agar tercipta adanya jarak kontak antarmasyarakat di Pademangan. Kehadiran fasilitas umum dan ruang hijau turut serta menciptakan jarak kontak antar masyarakat di samping menurunkan tingkat kepadatan. Penelitian ini menggunakan pendekatan deskriptif kualitatif, dengan jenis data primer berupa hasil survey dan studi lapangan juga data sekunder yang diperoleh dari data pemerintah, jurnal penelitian, dan buku. Teknik pengumpulan data menggunakan metode komparasi, metode penampalan, dan metode analisis dengan menggunakan konsep Solid-Void dan Arsitektur Organik. Konsep hidup bersih dan sehat tercipta pada bangunan dengan konsep yang terilhami dari masker yang terdiri dari 3 lapisan tetapi masih bisa "bernafas" yang terdiri dari breath brick dan lapisan $\mathrm{TiO}_{2}$. Selain itu, ruang interaksi antar masyarakat juga tercipta pada lantai dasar rumah susun yang dijadikan sebagai area publik yang terdiri dari taman, kantin, gym, market, dan retail shop sebagai tempat transaksi jual-beli.
\end{abstract}

Kata kunci: berhuni; bersih; kepadatan tinggi; sehat

\begin{abstract}
The world was shaken at the beginning of 2020 with the news of Covid-19 Virus. Indonesia is one of the countries affected by the impact, especially in Jakarta, that is still in a red zone area, which is one of the areas with the highest Covid-19 cases in Jakarta is West Pademangan in North Jakarta. West Pademangan is one of residential area with the highest population density, with a lot of slum settlements and limited public facilites to support that area. This design aims to reduce the density of buildings in order to create a distance of contact between communities in Pademangan. The presence of public facilities and green spaces also creates contact distance between communities in addition to reducing the level of density. This study used a qualitative descriptive approach, with primary data in the form of survey results and field studies as well as secondary data obtained from government data, research journals, and books. The data collection technique uses the comparative method, the overlay method, and the analysis method using the Solid-Void concept and Organic Architecture. The concept of health and hygiene in the building is inspired by a concept of a medical mask which consists of 3 layers but still can "breathe" consisting of breath brick layer and TiO2 layer. In addition, a space for interaction between communities is also created on the ground floor of the flats which is used as a public area consisting of a garden, canteen, gym, market and retail shop as a place for buying and selling transactions.
\end{abstract}

\section{Keywords: dwelling; health; high density; hygiene}




\section{PENDAHULUAN}

\section{Latar Belakang}

Dunia diguncang pada awal tahun 2020 dengan adanya Virus Covid-19. Para ahli memprediksi bahwa kehadiran virus ini berdampak pada semua lini kehidupan manusia salah satunya konsep berhuni di masa depan. Indonesia menjadi salah satu negara yang terkena dampak, terutama di Jakarta. Kawasan Pademangan Barat, Jakarta Utara menjadi salah satu kawasan dengan jumlah penyebaran Covid-19 tertinggi. Wilayah Pademangan Barat tampaknya tidak mencerminkan kekhawatiran akan situasi pandemi ini (Kompas.id). Terlihat beberapa warga tidak menggunakan masker saat beraktivitas. Kegiatan juga tampak berjalan normal, seolah tidak ada situasi pandemi, sementara Pademangan merupakan kawasan pemukiman di Jakarta Utara yang sangat kumuh dan minim fasum untuk menunjang kawasan tersebut. Wilayah Pademangan sebagian besar dihuni oleh pekerja tingkat rendah dan informal dengan kepadatan penduduk yang sangat tinggi.

Health and Hygiene in High Density menjadi isu utama dalam Future Dwelling Based on Today yang akan dirancang dalam skala kawasan yaitu Pademangan Barat yang ditetapkan sebagai zona merah penyebaran kasus Covid-19. Penyebaran virus bergerak dengan cepat akibat pemukiman yang begitu padat yaitu dengan kepadatan sebesar $26172 \mathrm{jiwa} / \mathrm{km}^{2}$ yang mana rata-rata kepadatan penduduk di Jakarta sebesar $17880 \mathrm{jiwa} / \mathrm{km}^{2}$. Maka dari itu diperlukan rumah susun untuk mengurangi kepadatan dengan konsep bersih dan sehat serta dilengkapi fasilitas umum (taman baca dan olahraga) mengingat fasilitas publik dan penghijauan yang sulit ditemui di Pademangan Barat.

\section{Rumusan Permasalahan}

Wilayah Pademangan adalah wilayah yang sangat kumuh, padat, dan sangat tidak menjaga kesehatan. Pertumbuhan Covid-19 mengarah kepada wilayah yang padat dan kumuh.

\section{Tujuan}

Rancangan ini bertujuan untuk mengurangi kepadatan bangunan agar tercipta adanya jarak kontak antar masyarakat di Pademangan sehingga dapat menekan percepatan penularan penyakit. Kehadiran fasilitas umum dan ruang hijau turut serta menciptakan jarak kontak antar masyarakat di samping menurunkan tingkat kepadatan. Selain itu juga bertujuan untuk menciptakan gaya hdup yang bersih dan sehat yang diterapkan melalui bangunan.

\section{KAJIAN LITERATUR}

\section{Personal Hygiene}

Kebersihan diri adalah suatu ukuran untuk meningkatkan kebersihan dan kesehatan suatu individu demi keberlangsungan fisik dan psikologis yang sejahtera (Tarwoto, 2004). Untuk mengurangi percepatan penyebaran penyakit dan menjaga kualitas hidup manusia kedepannya maka diperlukan rutinitas gaya hidup bersih dan sehat. Kuman dan parasit cenderung tidak masuk ke tubuh jika individu tersebut memiliki kebiasaan kebersihan yang baik. Kebersihan diri dikutip oleh Departemen Kesehatan Pemerintah Australia sebagai berikut:

Kepadatan

Penghuni yang tinggal di rumah yang padat akan lebih dekat satu sama lain sehingga memudahkan penyebaran kuman antarindividu. Untuk kesehatan dan kenyamanan yang baik, jumlah orang yang perlu tinggal di rumah bergantung pada jumlah dan ukuran kamar tidur dan ketersediaan fasilitas lainnya.

\section{Jumlah dan ukuran kamar tidur}

Jumlah orang yang tidur di sebuah kamar akan bergantung pada jumlah udara yang tersedia untuk setiap orang. Merujuk pada publikasi Departemen Kesehatan Pemerintah Australia, setiap orang dewasa harus memiliki setidaknya $13 \mathrm{~m}^{3}$ udara dan setiap anak memiliki setidaknya $10 \mathrm{~m}^{3}$ udara di kamar tidur. 


\section{Ukuran dan ketersediaan fasilitas lainnya}

Fasilitas di dalam rumah mungkin tidak dapat menangani semua permintaan yang diberikan oleh penghuninya. Kepadatan rumah terjadi karena beberapa alasan, seperti keluarga yang tidak mampu membayar sewa rumah sendiri dan perlu tinggal dengan kerabat untuk berbagi biaya. Perlu diingat bahwa kepadatan yang berlebihan merupakan masalah kesehatan lingkungan yang signifikan di banyak komunitas

\section{Arsitektur Organik}

Agar bangunan menyatu dengan alam sekitarnya, digunakanlah pendekatan dengan prinsip Arsitektur Organik. Ada dua definisi arsitektur organik menurut Fleming, Honor dan Pevsner. Pertama-tama, arsitektur organik adalah istilah yang diterapkan pada bangunan yang diatur berdasarkan analogi biologis atau mengingatkan pada bentuk alam seperti bentuk biomorfik, misalnya (Pearson, 2002).

Definisi kedua, menurutnya, adalah pengertian yang Frank Lloyd Wright dan arsitek lain gunakan untuk arsitektur yang harmonis secara pandangan dan lingkungan, harmonis dengan tapak dan mencerminkan perhatian arsitek mengenai proses dan bentuk alam yang dihasilkannya. Berikut konsep dasar Arsitektur Organik (Pearson, 2002):

\section{Building as nature}

Arsitektur organik bersifat alamiah yaitu inspirasi utama dari arsitektur organik adalah alam. Bangunan arsitektur organik terinspirasi oleh ketidaksejajaran organisme biologis.

\section{Continuous present}

Arsitektur organik adalah desain yang terus berjalan. Arsitektur organik selalu dalam keadaan dinamis, namun tetap orisinil pada desainnya.

\section{Form follows flow}

Arsitektur Organik merupakan arsitektur yang bentuknya mengikuti energi yaitu menyesuaikan alam sekitarnya secara dinamis, bukan melawannya. Kategori alam pada hal ini contohnya sirkulasi udara, cahaya matahari, aliran air, energi bumi dan lainnya.

\section{Of the people}

Hubungan dengan pengguna bangunan juga dipengaruhi oleh desain arsitektur organik berupa aktivitas dan tujuan penggunaan bangunan, kebutuhan dan kenyamanan bagi penggunanya dan keinginan penggunanya. Salah satu gagasan yang melekat dalam Arsitektur Organik adalah metode komposisi yang bekerja dari dalam ke luar, yaitu kebutuhan dan harapan penghuni terkait dengan tampilan eksterior bangunan (Steadman, 2008).

\section{Of the hill}

Frank Lloyd Wright mengatakan bahwa sebuah bangunan dengan tapak lebih baik terhubung dengan 'of the hill' daripada 'on the hill'. Artinya, bangunan tersebut merupakan bagian dari tapak, bukan sekadar bangunan yang diletakkan di atas tapak.

\section{Of the materials}

Arsitektur organik juga dapat diekspresikan melalui bahan yang digunakan. Menurut Steadman (2008), bahan yang dipilih antara lain bahan alam, bahan lokal dan bahan yang mampu menghasilkan bentuk bebas. 


\section{Youthful and unexpected}

Arsitektur Organik biasanya memiliki karakter yang terlihat muda, interaktif, menarik dan terlihat ceria. Tsui (Rasikha, 2009) menyebutkan, bangunan organik terdiri dari unsur-unsur seperti: perubahan dan pergerakan fisik dari unsur maupun komponen bangunan, kontinuitas tampak maupun struktur, ruang terbuka dan bermacam-macam, denah dengan pola grid yang tidak teratur.

\section{Solid - Void}

Ruang 3 dimensi dianggap sebagai ruang positif jika memiliki bentuk yang ditentukan dan memiliki kesan batas atau ambang batas antara masuk dan keluar. Ruang positif dapat didefinisikan dalam jumlah yang tidak terbatas melalui titik, garis, bidang, volume padat, pepohonan, tepi bangunan, kolom, dinding, tanah miring, dan banyak elemen lainnya. Demikian penjabaran tentang ruang positif dan negative yaitu bergerak melalui ruang negatif dan berdiam di ruang positif, ruang positif selalu disukai orang untuk berlama-lama dan berinteraksi sosial, ruang negatif cenderung mendorong pergerakan daripada berhuni.

\section{METODE}

Ditinjau dari jenis dan pendekatan penelitian, pendekatan penelitian yang digunakan dalam penelitian ini adalah pendekatan deskriptif kualitatif, yaitu menganalisis, menggambarkan, dan meringkas berbagai kondisi, situasi, dan berbagai data yang dikumpulkan berupa hasil atau pengamatan mengenai masalah yang diteliti yang terjadi di lapangan (I Made Wirartha, 2006). Kemudian dari jenis data yang dipakai adalah data primer dan sekunder. Data primer adalah data utama yang dikumpulkan oleh peneliti melalui pengambilan data secara langsung di lapangan. Pada penelitian ini, jawaban data primer diperoleh dari hasil survey dan studi lapangan. Sedangkan, data sekunder adalah data valid yang berasal dari publikasi, jurnal, dan berbagai situs yang berkaitan dengan informasi yang dicari. Pada penelitian ini, jawaban data sekunder diperoleh dari data populasi di Pademangan Barat, jurnal penelitian, dan buku berujudul A Pattern Language karya Christoper Alexander dan New Organic Architecture: The Breaking Wave karya David Pearson

Dari teknik pengumpulan data, menggunakan metode komparatif, penampalan, dan analisis. Metode komparatif yaitu menganalisis kasus tertentu dengan melibatkan setidaknya dua observasi dari kasus lain, dalam hal ini mengkomparasi beberapa studi preseden untuk mendapatkan solusi yang terbaik dalam mengatasi kepadatan di wilayah Pademangan Barat. Metode overlays (penampalan) yaitu, menggunakan sejumlah peta di tempat proyek yang akan dibangun dan daerah sekitarnya di mana tiap peta menggambarkan komponen-komponen lingkungan. Data ini akan diolah untuk mencari potensi pada lingkungan proyek.

Kemudian, dibutuhkan analisis dari data yang telah dikumpulkan sebagai tahap perencanaan dan perancangan bangunan hunian berupa rumah susun dan fasilitas umum ini. Data tersebut akan menjadi bahan pertimbangan untuk keputusan desain bangunan rumah susun dan fasilitas umum. Setelah itu, menguraikan aplikasi prinsip-prinsip Arsitektur Organik dan Solid-Void yang dapat diterapkan pada rumah susun dan taman baca. Prinsip-prinsip ini kemudian ditelaah kembali untuk dapat menentukan strategi perancangan dalam menjawab persoalan desain dari rumah susun dan taman baca.

\section{DISKUSI DAN HASIL}

Persoalan tapak dibagi ke dalam dua bagian yaitu pemilihan tapak dan pengolahan tapak. Pemilihan kawasan dibenahi dengan teori Solid-Void. Pengolahan tapak menjawab respon desain pada tapak terpilih dengan prinsip Arsitektur Organik yaitu prinsip continuous present dan of the hill. Hubungan bangunan dan tapak dapat tercapai melalui kondisi iklim dan karakter tapak, aspek ekologis dan tata lansekap. Aspek ekologisnya terlihat pada sistem pencahayaan dan penghawaan yang memaksimalkan pencahayaan dan penghawaan alami. Aspek ekologis dapat dilihat juga melalui tata 
lansekapnya. Program ruang diterapkan melalui prinsip ke empat yaitu of the people. Program ruang rumah susun dan taman dipengaruhi oleh gaya internal yaitu aktivitas dan kenyamanan pengguna, kebutuhan, kriteria, dan zoning ruang. Prinsip youthful and unexpected juga akan ditampilkan melalui tata letak ruang, keberagaman bentuk ruang dan level lantai.

Penataan dan bentuk massa bagungan menghasilkan bentuk bangunan yang atraktif dengan menerapkan prinsip building as nature, dimana bentuk bangunan terinspirasi dari bentuk-bentuk biomorfik. Selain itu, pentaan dan bentuk massa bangunan juga dipengaruhi oleh gaya eksternal, seperti keadaan cuaca dan iklim tapak dengan penerapan poin form follows flow.

\section{Analisis Kawasan}

Melihat kondisi yang tertera pada data dan karaketiristik wilayah, maka diperlukan pembenahan terhadap bangunan-bangunan yang kumuh dan tidak layak. Bangunan yang padat ini akan ditata dengan ketinggian yang dimaksimalkan sehingga dapat dijadikan area fasilitas bersama pada ruang yang tersisa. Diketahui bahwa fasilitas yang saat ini dibutuhkan berupa ruang terbuka hijau, beserta fasilitas olahraga dan sarana bagi warga untuk berkomunitas. Dengan pembenahan kepadatan, maka penyebaran virus dapat diperlambat, juga pada masa depan isu kebersihan dan kesehatan dapat teratasi dengan program bangunan yang akan dibangun dengan teori Arsitektur Organik dan SolidVoid. Lahan solid (hunian horizontal) ini akan dikupas dan digantikan dengan hunian vertikal dan area hijau. Proyek utama ditandai dengan titik berwarna ungu berupa hunian mengingat bahwa kebutuhan hunian di Pademangan Barat sangat tinggi. Titik berwarna hijau merupakan fasilitas publik berupa taman baca dan olahraga sebagai sarana untuk bersosialisasi warga mengingat bahwa area penghijauan yang sangat minim dan ketergantungan warga pada gadget yang menurunkan interaksi sosial bagi kaum milenial (Gambar 1). Pada setiap kelurahan terdapat 1-3 fasilitas publik tergantung dari luas tiap kelurahan.

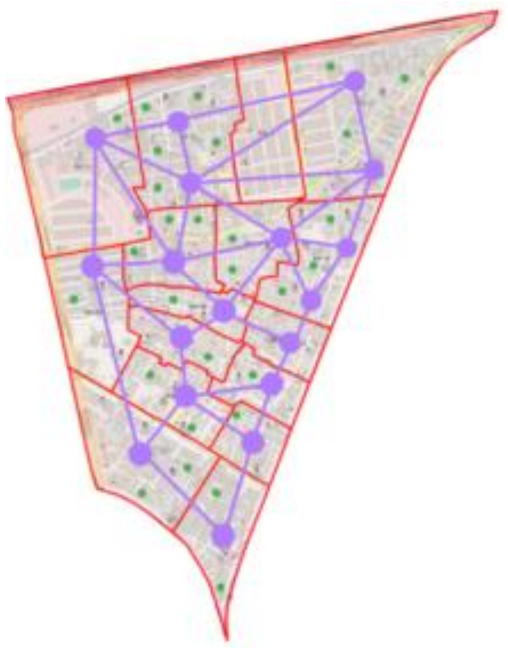

Gambar 1. Peta Pembagian Kawasan Pademangan Barat

Sumber: Penulis, 2020

\section{Kapasitas}

Proyek ini nantinya akan dijadikan tipologi pada kawasan lainnya yang memiliki kepadatan penduduk tinggi. Pada kasus ini, diambil contoh yaitu wilayah RW 7. RW 7 memiliki luas $65.000 \mathrm{~m}^{2}$ dengan KDB $60 \%$ dan RTH 20\%. Luas tapak hunian sebesar $5500 \mathrm{~m}^{2}$ dan taman baca $2975 \mathrm{~m}^{2}$. Setelah perhitungan, rumah susun harus dapat menampung $105 \mathrm{KK}$, sehingga minimal jumlah kamar adalah 105 unit.

\section{Analisis Tapak dan Proses Gubahan Massa}

Analisis tapak dicapai dengan penggunaan prinsip Arsitektur Organik, dengan penjabaran berikut: 


\section{Building as Nature}

Penataan dan bentuk massa bangunan menekankan pada bentuk biomorfik yang dinamis dan memiliki kecenderungan kolom yang tidak teratur sehingga menciptakan kesan dan pengalaman ruang yang berbeda (Gambar 2).

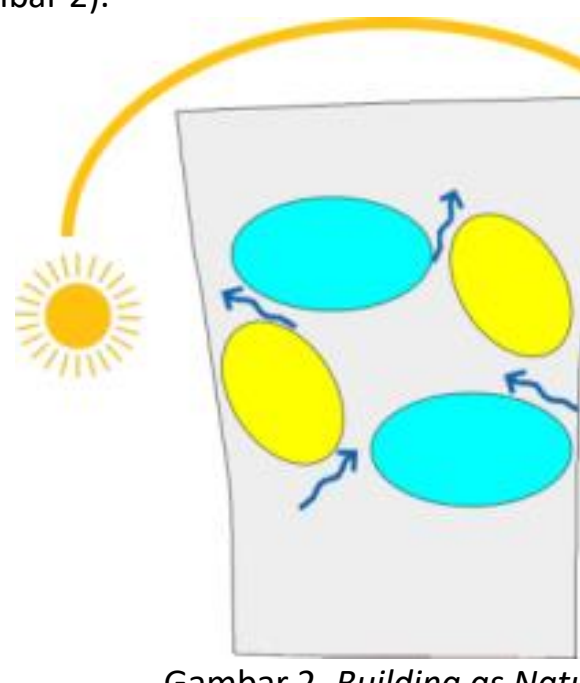

Gambar 2. Building as Nature

Sumber: Penulis, 2020

\section{Form Follows Flow}

Bentuk dan tata massa bangunan dipengaruhi oleh energi eksternal seperti energi matahari dan angin. Digabungkan ke dalam kelompok massa. Kemudian massa tersebut dipusatkan pada ruang sosial berupa taman dan area komunal. Sistem tata massa dan pola pada bangunan ini dapat mendukung terjadinya interaksi sosial dan kolaborasi (Gambar 3).

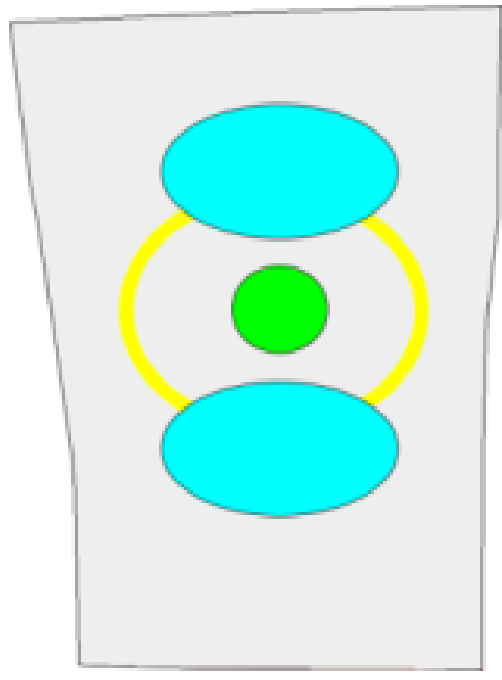

Gambar 3. Form Follows Flow

Sumber: Penulis, 2020

\section{Of The Hill}

Dapat diartikan bahwa bangunan merupakan bagian dari tapak, bukan sekadar bangunan yang diletakkan di atas tapak. Untuk memperoleh respon desain yang baik terhadap kondisi dan lingkungan tapak dilakukan analisis pencapaian dan iklim serta lingkungan tapak. Analisis pencapaian dilakukan bertujuan untuk menentukan pintu masuk utama atau main entrance (ME) dan pintu samping atau side entrance (SE) sebagai jalan masuk menuju tapak. 


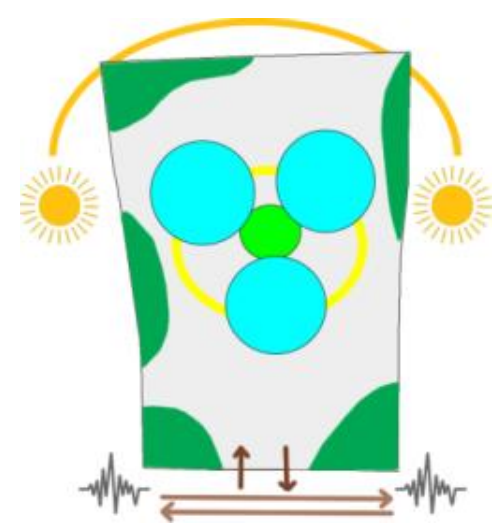

Gambar 4. Of The Hill

Sumber: Penulis, 2020

Penentuan ME dan SE dipengaruhi oleh sirkulasi kendaraan pada area tapak, ME berada pada arah bagian utara sebagai jalur kendaraan utama bagi penghuni, pengunjung, maupun para pekerja rumah susun. Sedangkan SE adalah jalur masuk servis. Analisis cahaya matahari bertujuan untuk menghasilkan kenyamanan pada konfigurasi ruang dan massa bangunan agar cahaya matahari yang masuk optimal tetapi tidak mengganggu kenyamanan pelaku kegiatan dalam bangunan. Analisis sirkulasi udara bertujuan untuk memaksimalkan penghawaan yang baik dalam bangunan dengan respon desain yang tepat agar angin dapat masuk ke dalam tapak sehingga mengurangi penggunaan AC. Analisis kebisingan bertujuan untuk menjaga bangunan terhadap kebisingan dari luar tapak sehingga memiliki kebutuhan ruang yang tenang untuk ruang-ruang tertentu dapat tercapai.

\section{Youthful and Unexpected}

Konfigurasi ruang terdiri dari bentuk-bentuk yang dinamis sehingga tercipta suatu ruang gerak yang fleksibel dan memudahkan adanya interaksi dan kolaborasi. Permainan ketinggian plafond dan lantai, juga penggunaan void dan mezzanine dapat menciptakan suatu kesan ruang tertentu. Sistem struktur bangunan menggunakan sistem struktur yang dapat mendukung bentuk yang fleksibel.

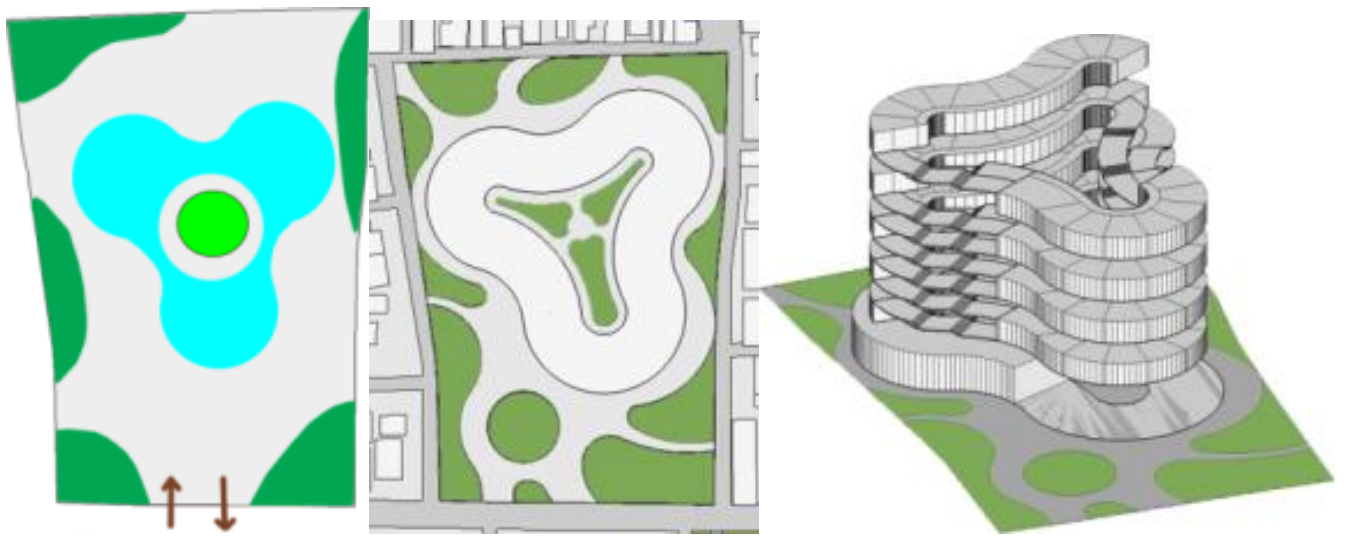

Gambar 5. Youthful and Unexpected

Sumber: Penulis, 2020

\section{Program Ruang}

\section{Rumah Susun}

Kebutuhan ruang di dalam rumah susun dan taman baca ini didasari oleh aktivitas yang dilakukan oleh pelaku kegiatan yaitu penghuni, pekerja, dan pengunjung. Aktivitas dari pelaku-pelaku kegiatan tersebut membutuhkan ruang khusus di dalamnya, dari keseluruhan aktivitas/ kegiatan yang dilakukan oleh berbagai macam pelaku tersebut yang akan dijabarkan melalui tabel berikut: 
Tabel 1. Tabel Program Ruang Rumah Susun

\begin{tabular}{|c|c|}
\hline \multicolumn{2}{|c|}{ Rumah Susun } \\
\hline Kelompok Ruang & Ruang \\
\hline \multicolumn{2}{|c|}{ Kelompok Kegiatan Penerimaan } \\
\hline \multirow[t]{3}{*}{ Kelompok Ruang Penerimaan } & Parkir pengunjung, pengelola, penghuni \\
\hline & Entrance Hall \\
\hline & Lobby \\
\hline \multicolumn{2}{|c|}{ Kelompok Kegiatan Utama } \\
\hline Kelompok Ruang Hunian & Kamar hunian \\
\hline \multicolumn{2}{|c|}{ Kelompok Kegiatan Penunjang } \\
\hline \multirow[t]{2}{*}{ Kelompok Ruang Komunal } & Area komunal \\
\hline & Taman \\
\hline \multirow[t]{3}{*}{ Kelompok Area Bisnis } & Retail Shop \\
\hline & Market \\
\hline & ATM \\
\hline \multirow[t]{2}{*}{ Kelompok Area Olahraga } & Gym \\
\hline & Outdoor Workout Space \\
\hline Kelompok Area Farming & Farm \\
\hline \multicolumn{2}{|c|}{ Kelompok Kegiatan Pengelola dan Servis } \\
\hline \multirow[t]{4}{*}{ Kelompok Ruang Pengelola } & Ruang pengelola \\
\hline & Ruang staff \\
\hline & Ruang penerima tamu \\
\hline & Ruang surat \\
\hline \multirow[t]{11}{*}{ Kelompok Ruang Servis } & Ruang sampah \\
\hline & Gudang \\
\hline & Ruang trafo \\
\hline & Ruang genset \\
\hline & Ruang panel \\
\hline & Ruang PLN \\
\hline & Ruang pompa \\
\hline & Ruang STP \\
\hline & Ruang resevoir bawah \\
\hline & Ruang janitor \\
\hline & Loading dock \\
\hline
\end{tabular}

Sumber: Penulis, 2020

\section{Taman Baca}

Taman baca diperuntukkan bagi warga Pademangan Barat sebagai wadah untuk bersosialisasi dan kolaborasi terkait dengan minimnya interaksi sosial pada generasi milenial, yang terdiri dari area bermain, performance area, street workout, dan perpustakaan yang dijabarkan melalui tabel berikut:

Tabel 2. Tabel Program Ruang Taman Baca

\begin{tabular}{|c|c|}
\hline \multicolumn{2}{|c|}{ Taman Baca } \\
\hline Kelompok Ruang & Ruang \\
\hline \multicolumn{2}{|c|}{ Kelompok Kegiatan Penerimaan } \\
\hline \multirow[t]{2}{*}{ Kelompok Area Komunal } & Area Bermain \\
\hline & Performance Area \\
\hline \multirow[t]{2}{*}{ Kelompok Area Olahraga } & Street Workout \\
\hline & Jogging Area \\
\hline \multirow[t]{4}{*}{ Kelompok Area Baca } & Area rak buku \\
\hline & Area baca \\
\hline & Gudang \\
\hline & Area Penerimaan \\
\hline
\end{tabular}

Sumber: Penulis, 2020

Area bermain diperuntukkan bagi anak-anak untuk meningkatkan kinerja motorik pertumbuhan pada anak juga sebagai wadah interaksi bagi mereka untuk berkomunikasi dengan teman sebaya. 
Performance Area dapat digunakan sebagai area untuk pertunjukan bakat dan seni. Jika sedang tidak digunakan, area ini juga dapat dijadikan sebagai area berkumpul dan bersantai. Perpustakaan terdiri dari 2 lantai. Kedua lantai ini terdapat area baca dan membaca. Perpustakaan dihadirkan untuk meningkatkan kualitas berpikir sejak dini, juga dapat dijadikan sebagai tempat untuk belajar bersama.

\section{Konsep Perancangan}

\section{Rumah Susun}

Konsep bangunan terinspirasi dari masker yang terdiri dari 3 lapisan tetapi "dapat bernafas". Masker terdiri dari 3 lapisan, yaitu lapisan luar, lapisan tengah, dan lapisan dalam. Lapisan ini akan dijadikan sebagai wajah bangunan yaitu pada bagian eksterior. Lapisan luar memiliki sifat hydrophobic yaitu lapisan yang tidak dapat menyerap air. Lapisan tengah adalah sebagai filter udara agar kotoran maupun virus dari udara tidak terhirup. Lapisan dalam adalah sebagai penyerap. Lapisan tengah dan dalam bangunan dintepretasikan dengan material breath brick. Breath brick dirancang dengan menggunakan sistem dua dinding dari bata khusus pada bagian luar yang dilengkapi dengan insulasi lapisan internal standar. Batu beton dan coupler plastik daur ulang adalah dua sistem dasar yang digunakan. Keduanya membantu sirkulasi udara dari luar ke dalam bangunan. Sistem ini diketahui dapat menyaring $30 \%$ partikel halus dan $100 \%$ polutan kasar.

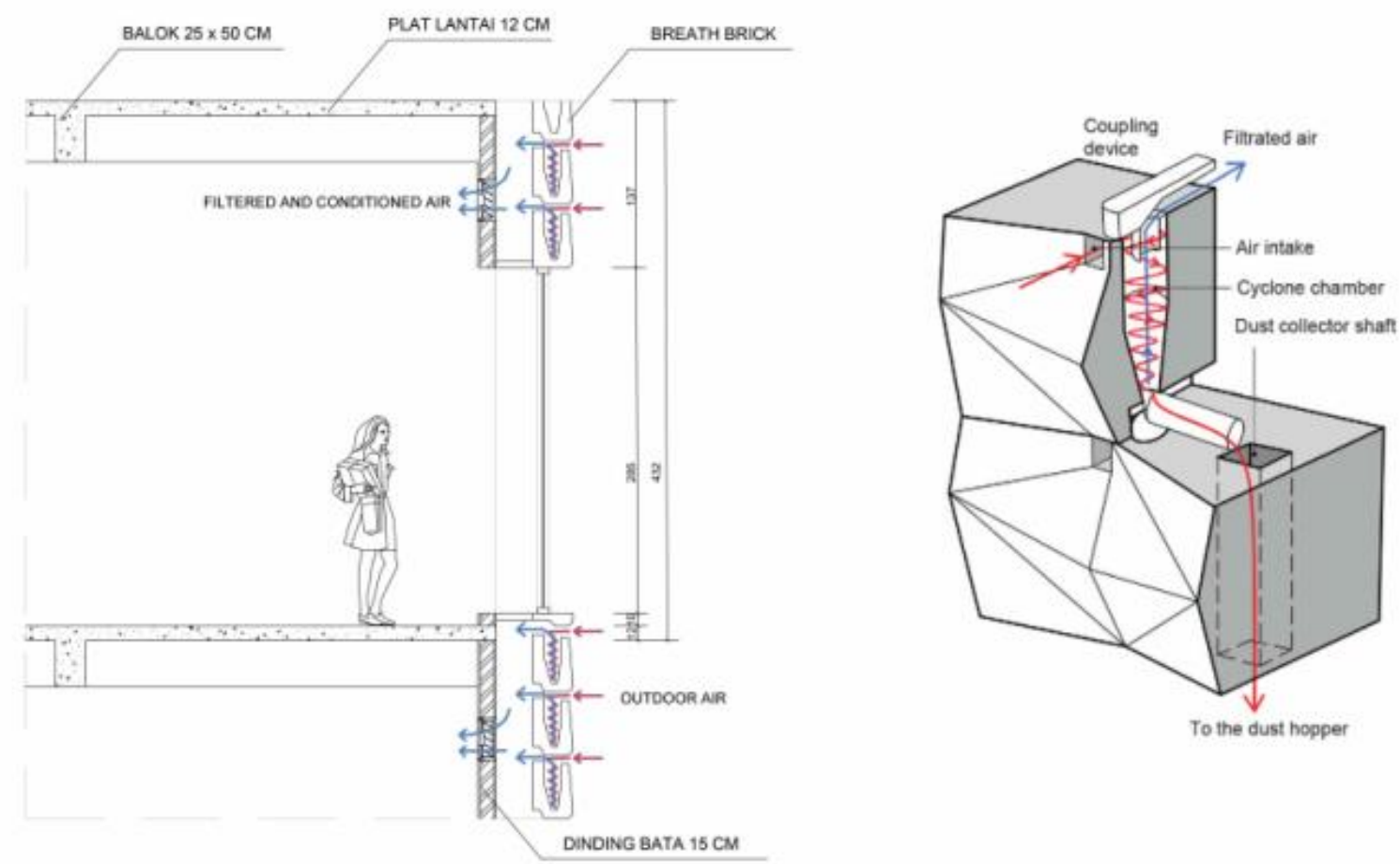

Gambar 6. Detail Breath Brick

Sumber: Penulis, 2020

Bangunan juga menggunakan pencahayaan dan penghawaan alami untuk mengurangi penggunaan AC. Sistem penghawaan alami dimaksimalkan dengan sistem stack effect. Stack effect adalah pergerakan udara pada bangunan dengan daya penggerak bouyancy atau daya apung. Molekul udara yang dengan suhu lebih tinggi kerapatan antarmolekul merenggang, sehingga massa jenis akan lebih ringan, dan udara pun bergerak menuju ke atas. 


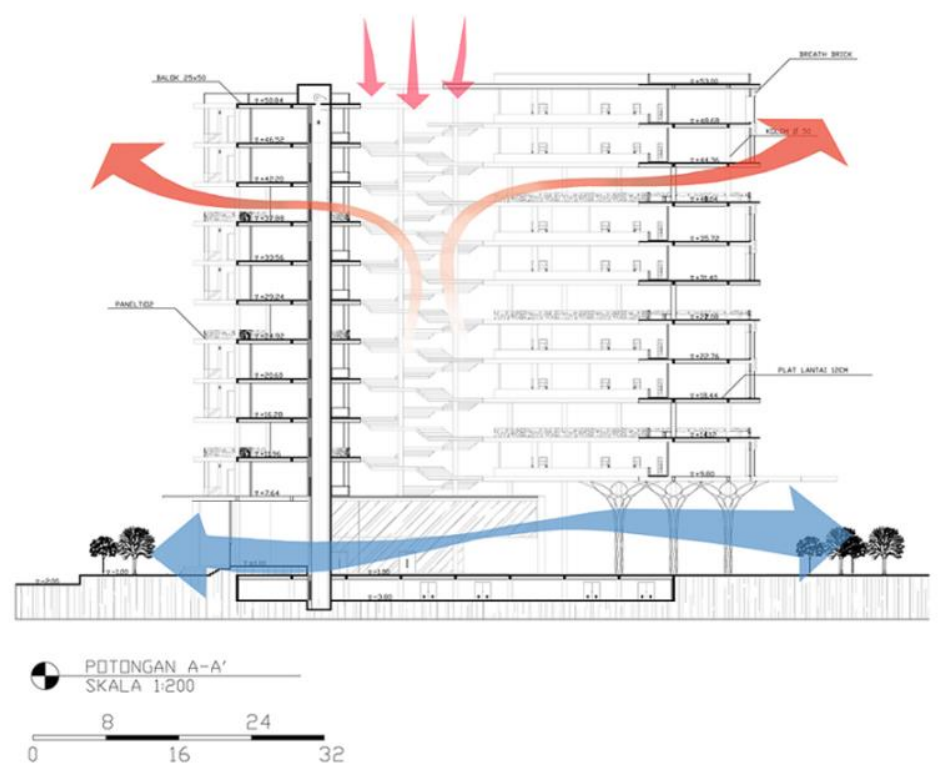

Gambar 7. Sistem Stack Effect

Sumber: Penulis, 2020

Hunian dirancang dengan single loaded agar koridor dapat terpapar cahaya matahari. Selain itu, bagian koridor hunian dirancang dengan lebar sekitar 2 meter pada area hunian agar tidak terjadi pemadatan manusia yang berjalan di area koridor. Pada koridor juga terdapat uwabaki area, yaitu area di mana penghuni harus melepas sepatunya dan digantikan dengan sendal yang disediakan oleh pihak manajemen, sehingga koridor bersih dari debu maupun kotoran yang tertempel pada sepatu. Untuk mencegah panasnya sinar matahari, maka digunakan tinted glass yaitu kaca yang dapat berubah warna mengikuti suhu. Kaca ini akan ditempatkan pada jendela tiap kamar hunian pada rumah susun. Pada bagian entrance hall diberikan aksen berupa kanopi dan ornamen pada kolom sehingga lebih menarik.

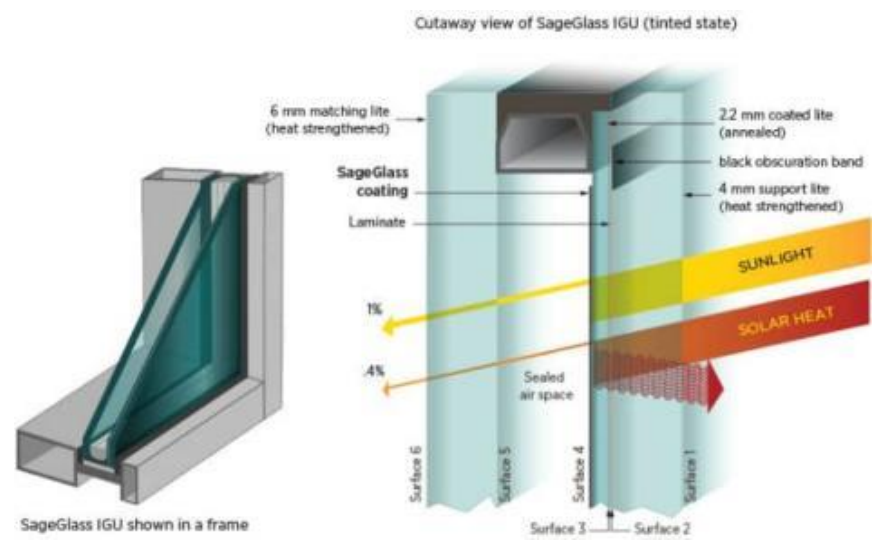

Gambar 8. Tinted Glass

Sumber: https://www.postscapes.com/self-tinting-windows-sageglass/

Rencana farm dibagi menjadi 5 bagian (Gambar 9). Setiap sayur dan buah yang ditanam berdekatan berpengaruh kepada tumbuh suburnya sayur dan buah, juga terkait dengan pencegahan hama. Tanaman ini nantinya akan dipanen dan dijual ke penghuni melalui market yang berada di lantai dasar. Struktur dari medianya itu sendiri terdiri dari lapisan beton, Root repellent (waterproof base), Support panel, Tempat penampungan air, dan Media tanah (kompos 20\%, tanah 20\%, pasir 50\%).

Jenis tanaman yang ditanam 1. Padi; 2. Bayam, kol, brokoli, kale; 3. Tomat, wortel, bawang bombay, calendula; 4. Kacang polong, kacang-kacangan, kentang, calendula, 5. Jagung, timun, kol, kacangkacangan 


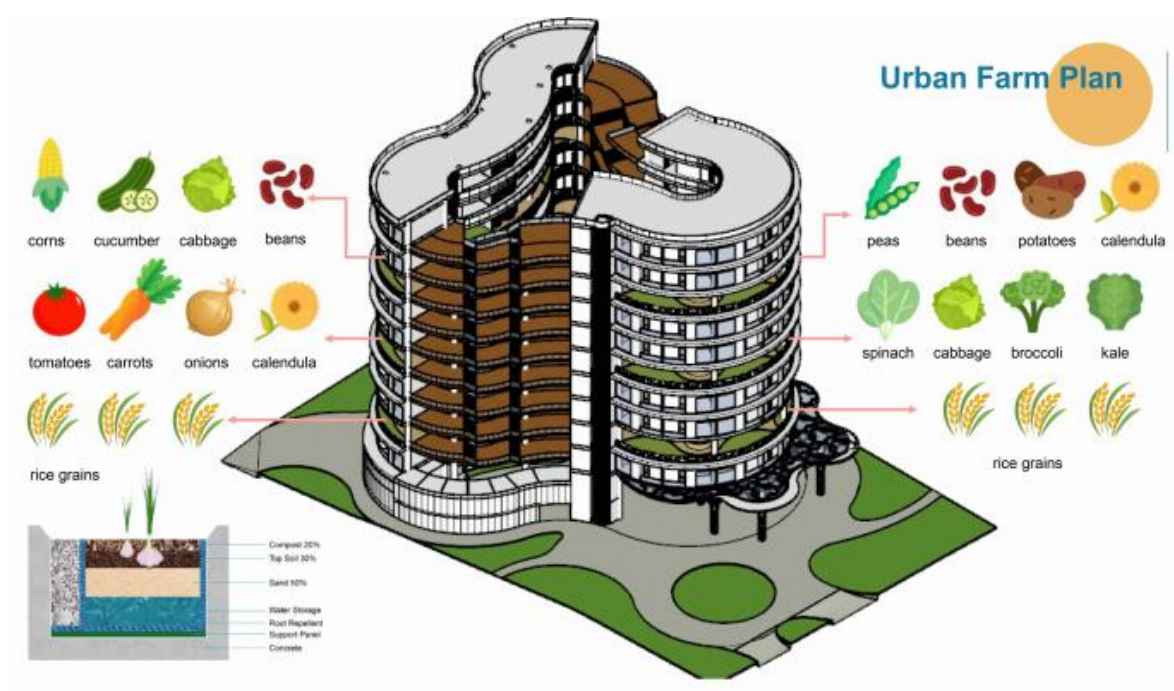

Gambar 9. Urban Farm Plan

Sumber: Penulis, 2020

Kamar hunian memiliki luasan sebesar $16 \mathrm{~m}^{2}$ yang dapat dihuni oleh 2-3 orang. Pada bagian interior konfigurasi ruangannya juga dirancang dengan pengaplikasian konsep bersih dan sehat, yang akan dijabarkan sebagai berikut:

Tabel 3. Konfigurasi Ruang

1. Terdapat area foyer, kamar mandi, dan area sanitasi pada bagian depan. Area ini disebut juga sebagai area kotor. Area ini dipisahkan dengan area dalam dengan perbedaan level lantai agar tercipta perbedaan ruang. Area foyer adalah area untuk menaruh sepatu yang kotor atau barang belanjaan. Lalu selepas berpergian dari luar, penghuni diharapkan dapat membersihkan dirinya dengan mandi atau mencuci tangan terlebih dahulu sebelum masuk ke area bersih.

2. Langit-langit ruangan yang tinggi agar sistem sirkulasi udara lebih baik. Kamar ini memiliki ketinggian 3,82 meter. Exhaust fan dan ventilasi di atas pintu balkon membantu pertukaran udara di kamar.

3. Pada area dapur menggunakan material yang bersifat hydrophobic pada permukaannya, contohnya keramik, sehingga kotoran tidak menempel dan mudah dibersihkan

4. Memulai indoor home garden untuk meningkatkan kepedulian penghuni terhadap lingkungan. Selain itu juga menciptakan suasana yang asri. Tanaman pun dapat menghindarkan penghuni dari serangga tergantung dari jenis tanaman yang ditanam.

5. Kamar dicat berwarna putih agar menciptakan suasana yang bersih. Selain itu kotoran dan debu mudah terlihat sehingga dapat langsung dibersihkan.

6. Untuk memaksimalkan ruangan, terdapat area tidur tingkat dengan area penyimpanan dan tempat bekerja di bawahnya. Selain itu, terdapat area yang dapat disesuaikan dengan kebutuhan penghuni di depan jendela. Area ini dapat berupa area bersantai ataupun berolahraga.

7. Berbentuk $1 / 8$ lingkaran menyesuaikan dengan bentuk bangunan. Sumber: Penulis, 2020 


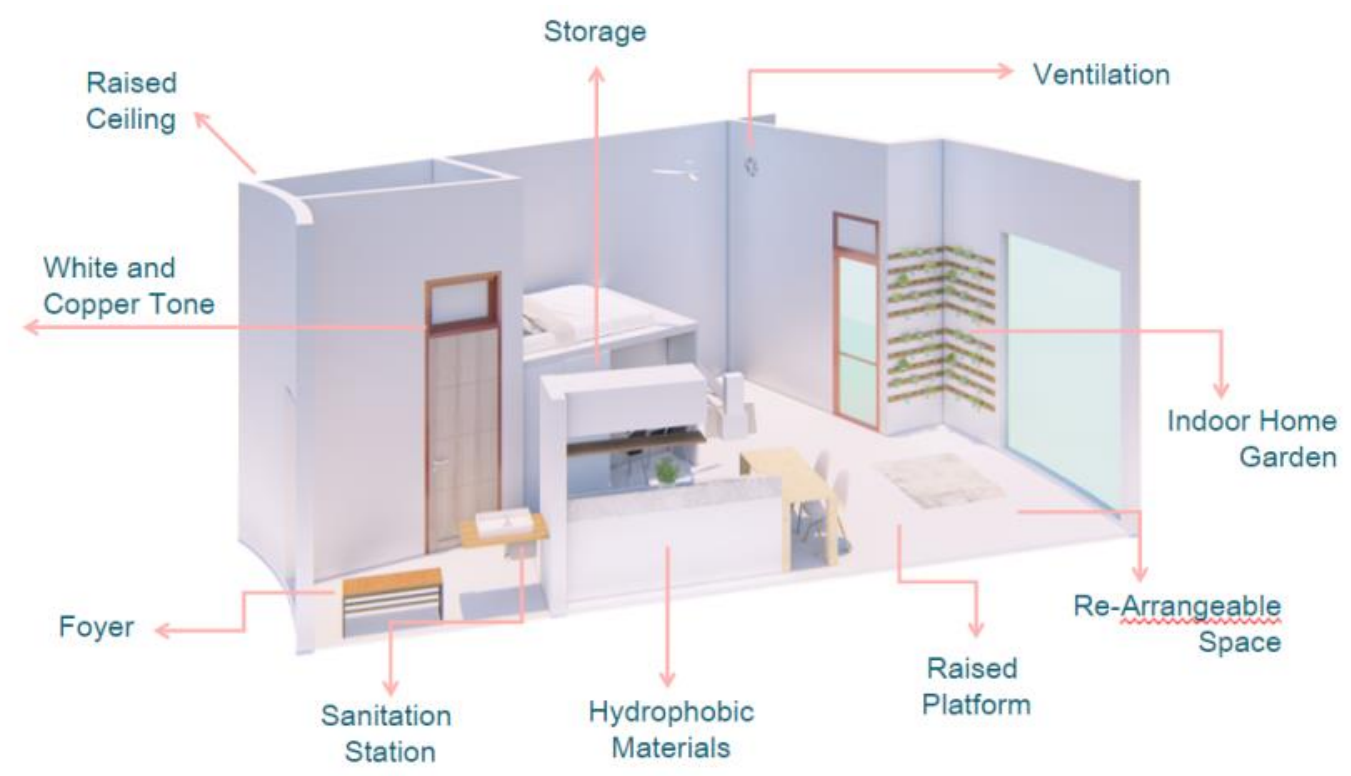

Gambar 10. Konfigurasi Ruangan Unit Hunian

Sumber: Penulis, 2020

Bangunan ini dibagi menjadi 2 tower dengan struktur yang digunakan ialah menggunakan kolom beton dengan bentang 5 meter. Atap yang digunakan adalah atap beton. Pada bagian lantai dasar, kolom diberi aksen agar lebih menarik. Terdapat tangga outdoor dengan ketinggian 2,16 meter. Selain sebagai sarana transportasi vertikal menuju hunian dan farm, tetapi juga sebagai area komunal. Terdapat area yang dapat dijadikan sebagai outdoor working space atau hanya sebagai area untuk berkumpul bersama.

\section{Taman Baca}

Taman baca diperuntukkan bagi warga Pademangan Barat dalam memenuhi kebutuhan ruang hijau dan area interaksi juga kolaborasi terkait dengan minimnya interaksi sosial pada generasi milenial. Penataan tata letak massa bangunan terinpirasi dari arsitektur organik yang dinamis (Gambar 11).

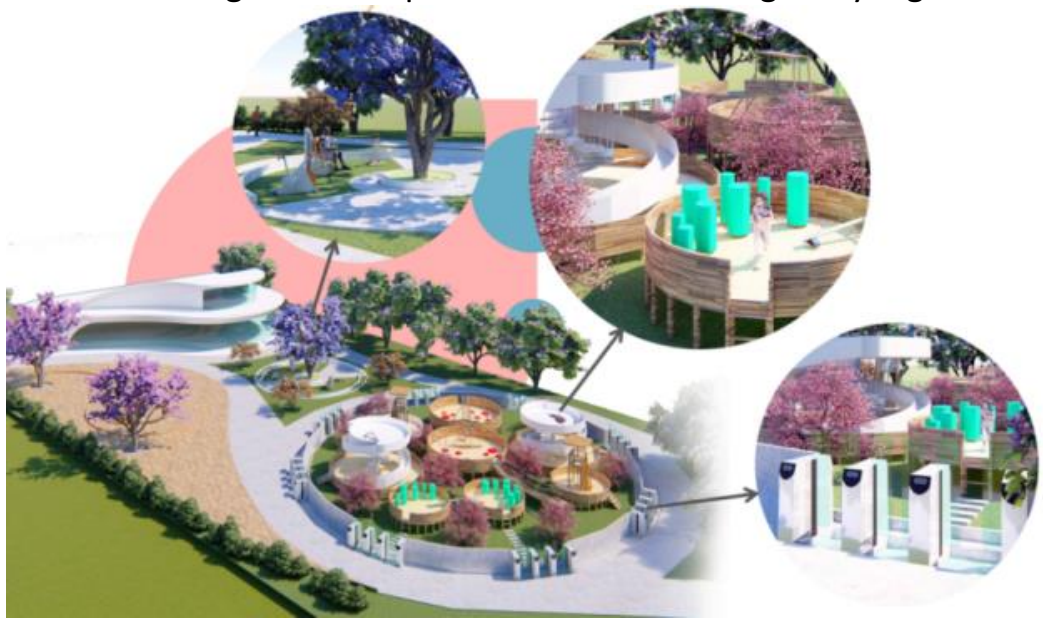

Gambar 11. Taman Baca

Sumber: Penulis, 2020

Air kotor bekas cuci kaki ini nantinya akan langsung terbuang dengan sistem flush dan pintu akan terbuka ketika tombol flush sudah ditekan. Terdapat area penyimpanan sepatu di antara area cuci kaki. Area bermain terdiri dari perosotan melingkar, jungkat -jungkit, ayunan, dan rumah pohon yang dikelilingi oleh hamparan rumput. Pada bagian tengah terdapat area street workout yaitu area untuk warga sekitar berolahraga dengan alat olahraga dengan ditanamnya pohon di tengah agar suasana 
tetap rindang. Performance Area dapat digunakan sebagai area untuk pertunjukan bakat dan seni. Jika sedang tidak digunakan, area ini juga dapat dijadikan sebagai area berkumpul dan bersantai.

Perpustakaan terdiri dari 2 lantai. Kedua lantai ini terdapat area baca dan membaca. Perpustakaan dihadirkan untuk meningkatkan kualitas berpikir sejak dini, juga dapat dijadikan sebagai tempat untuk belajar bersama. Bentuk bangunan terpengaruh dari gaya arsitektur organik dengan bentuk biomorfik. Kaca yang lebar menggunakan tinted glass agar dapat menyesuaikan dengan panas sinarnya matahari.

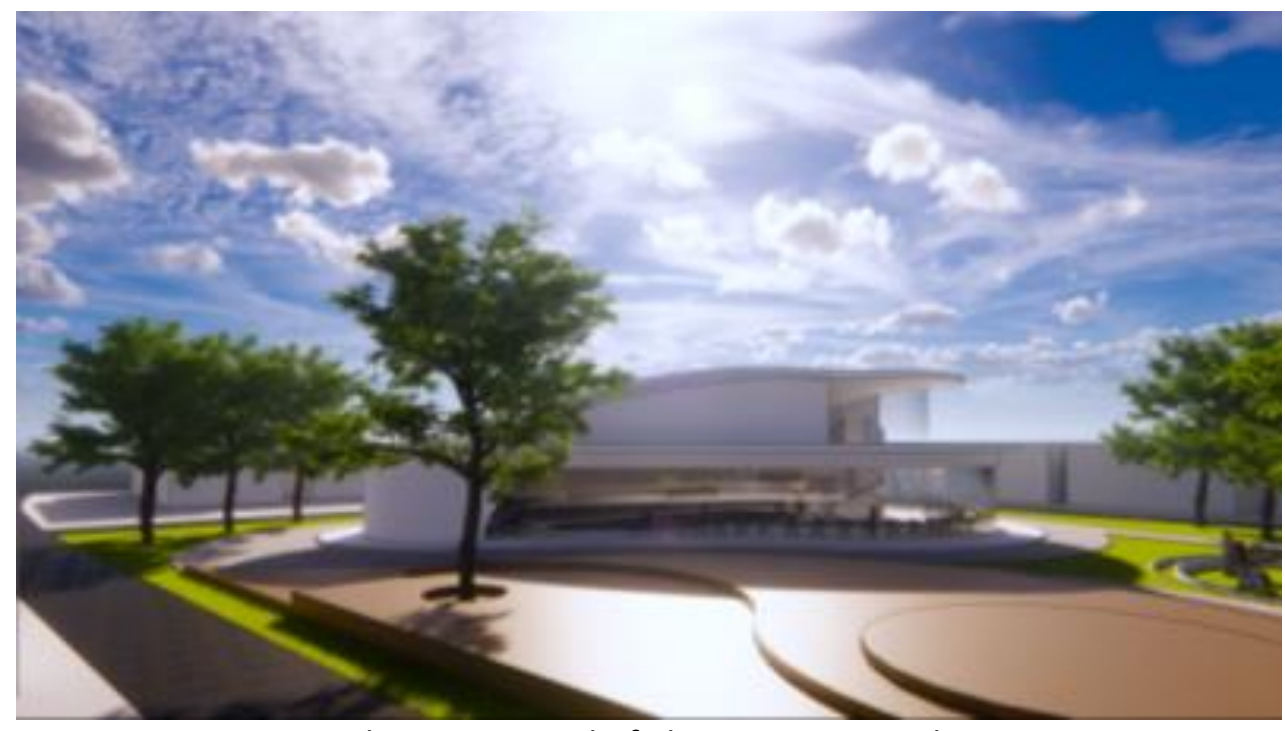

Gambar 12. Perspektif Eksterior Perpustakaan

Sumber: Penulis, 2020

\section{KESIMPULAN DAN SARAN}

\section{Kesimpulan}

Kepadatan penduduk dapat diatasi dengan membenahi kawasan dengan teori Solid-Void, yaitu pengupasan lahan dari hunian horizontal menjadi hunian vertikal, sehingga menyisakan ruang-ruang kosong yang dapat dijadikan sebagai ruang terbuka hijau dan fasilitas publik untuk menunjang kawasan Pademangan Barat. Terhitung jumlah orang yang dapat ditampung dalam hunian harus sesuai dengan kepadatan yang ada yaitu sebesar 105 KK. Pengaplikasian konsep hidup bersih dan sehat pada bangunan dapat mencegah penyebaran penyakit pada cara berhuni di masa yang akan datang, yang dapat diterapkan melalui pendekatan Arsitektur Organik yang mengandung unsur alam dan keterbukaan. Konsep hidup bersih dan sehat tercipta pada bangunan dengan konsep yang terilhami dari bentuk masker yang terdiri dari 3 lapisan tetapi masih bisa "bernafas" yaitu berupa panel TiO2 dan breath brick pada fasad. Selain itu sususnan konfigurasi ruang disusun dengan menerapkan konsep bersih dan sehat. Hasil dari sayur dan buah yang ditanam pada farm yang berada di bangunan, dijual kepada penghuni agar makanan yang dikonsumsi tetap sehat dan alami. Pada taman juga dirancang dengan konsep bersih dan sehat di mana anak-anak yang bermain harus mencuci kaki terlebih dahulu sebelum dan sesudah memasuki area bermain.

\section{Saran}

Dalam pembuatan rumah susun dan taman baca dengan konsep hidup bersih dan sehat ini diperlukan pengembangan lebih lanjut lagi. Adapun saran yang dapat diberikan untuk mendapatkan hasil yang lebih baik adalah sebagai berikut: diperlukan wawancara lebih lanjut terkait dengan situasi ini pada keadaan yang lebih kondusif. 


\section{REFERENSI}

Alexander, C. (1977). A Pattern Language: Towns, Buildings, Construction. London: Oxford University Press.

Atmadja, F. P. S. (2015). Konsep Hunian Vertikal Sebagai Alternatif Untuk Mengatasi Masalah Permukiman Kumuh, Kasus Studi Kampung Pulo. Malang: Universitas Brawijaya.

Australian Government Department of Health, 7 Personal hygiene, https://www1.health.gov.au/internet/publications/publishing.nsf/Content/ohp-enhealthmanual-atsi-cnt-I ohp-enhealth-manual-atsi-cnt-I-ch3 ohp-enhealth-manual-atsi-cnt-I-ch3.7

Badan Pusat Statistik Jakarta Utara. (2019). Kecamatan Pademangan Dalam Angka 2019. Badan Pusat Statistik Jakarta Utara: Jakarta.

Fang, F. (2019). Perancangan Hunian Sewa Untuk Milenial di Pademangan. Sains, Teknologi, Urban, Perancangan, Arsitektur (Stupa).1(2). Pp. 1433-1442. DOI: 10.24912/stupa.v1i2.4452

Heidegger, M. (1971). Building Dwelling Thinking. New York: Harper Colophon Books.

Jakarta Vertical Kampung Master Class, 2020, diakses 10 November 2020, http://www.jakartaverticalkampung.org/

Margianto, Heru, 2020, Wabah Penyakit Menular Terjadi Setiap 100 Tahun, diakses 15 Agustus 2020, https://www.kompas.com/tren/read/2020/03/24/124434465/wabah-penyakit-menular-terjadisetiap-100-tahun?page=all.

Norberg-Schulz, C. (1985). The Concept of Dwelling: On the Way to Figurative Architecture. New York: Rizzoli

Pearson, D. (2001). New Organic Architecture. London: Gaia Books Limited

Peta Sebaran Kasus Per Provinsi, diakses 25 Agustus 2020, https://covid19.go.id/peta-sebaran

Rasikha, T. (2009). Arsitektur Organik Kontemporer. (skripsi) Depok: Universitas Indonesia. http://www.beta.lecture.ub.ac.id/files/2014/06/MINGGU-14-ORGANIK-KONTEMPOERER.pdf

Sebagian Warga Makin Apatis Menghadapi Lonjakan Kasus Covid-19, diakses 25 Agustus 2020, https://www.kompas.id/baca/metro/2020/07/14/sebagian-warga-makin-apatis-menghadapilonjakan-kasus-covid-19/?utm_source=medsos_facebook_kompasdata\&utm_medium=link

Steadman, P. (2008). The Evolution of Design: Biological Analogy in Architecture and Applied Arts; Revised Edition. New York: Routledge.

Velarosdela, R. N. (2020) Daftar 25 Kelurahan Kasus Tertinggi Covid-19 di Jakarta, Tertinggi di Pademangan Barat, diakses 1 Agustus 2020, https://megapolitan.kompas.com/read/2020/07/27/10104061/daftar-25-kelurahan-kasustertinggi-covid-19-di-jakarta-tertinggi-di.

Wirartha, I. M. (2006). Pedoman Penulisan Usulan Penelitian, Skripsi dan Tesis. Yogyakarta: Penerbit Andi. 